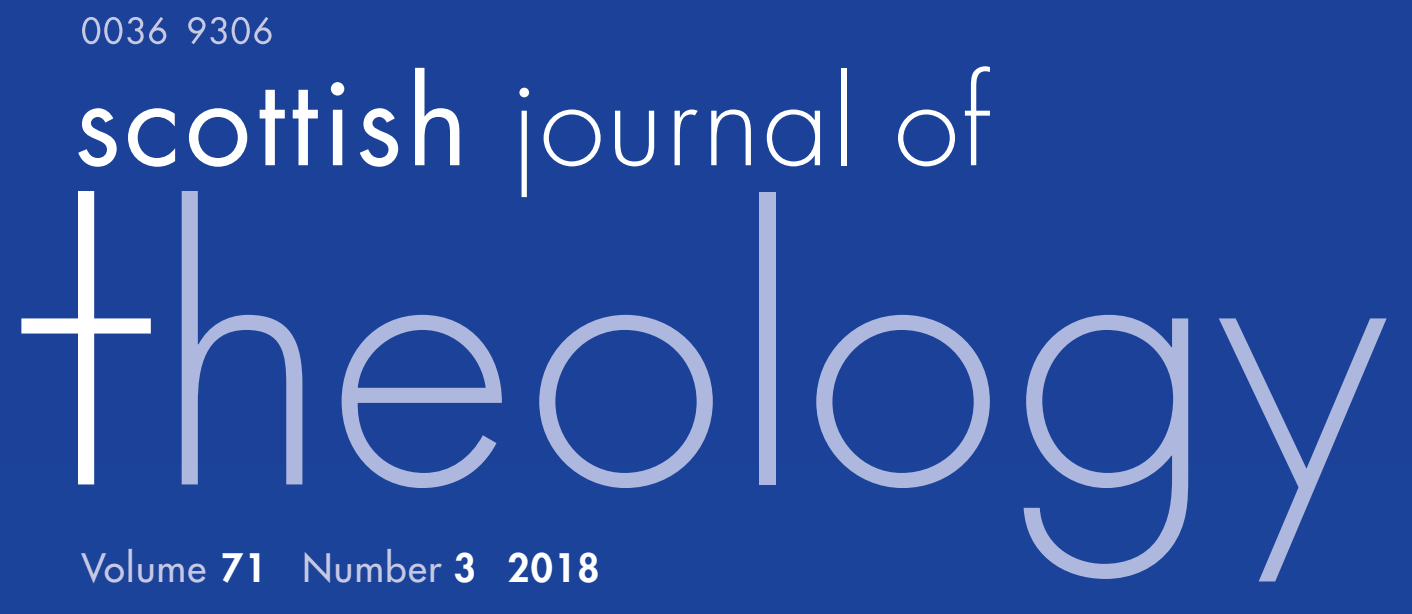


Editor

Ian A. McFarland

University of Cambridge, UK

Email: scottishjt@cambridge.org

\section{Editorial Assistant}

\section{E. S. Kempson}

University of Cambridge, UK

\section{Consulting Editors}

\section{James Edwards}

Whitworth University, Spokane, Washington, USA

\section{David Fergusson}

University of Edinburgh, Scotland, UK

\section{David Ford}

University of Cambridge, UK

\section{Stanley Hauerwas}

Duke Divinity School, USA

\section{Willie Jennings}

Yale Divinity School, USA

Paul Joyce

King's College, London, UK

Karen Kilby

Durham University, UK

Lois Malcolm

Luther Seminary, St Paul, USA

Joseph Mangina

Wycliffe College, Toronto, Canada

Bruce L. McCormack

Princeton Theological Seminary, New Jersey, USA

\section{Paul Molnar}

St John's University, Queens, New York, USA
Francesca Murphy

University of Notre Dame, USA

\section{Aristotle Papanikolaou}

Fordham University, USA

\section{Amy Plantinga Pauw}

Louisville Presbyterian Theological Seminary, Louisville, Kentucky, USA

\section{Kang Phee Seng}

China Graduate School of Theology, Hong Kong

\section{Katherine Sonderegger}

Virginia Theological Seminary, USA

\section{Kathryn Tanner}

Yale Divinity School, Yale, USA

Leanne Van Dyk

Columbia Theological Seminary, USA

\section{Dawn DeVries}

Union Theological Seminary, Richmond, Virginia, USA

\section{Michael Weinrich}

University of Bochum, Germany

\section{Subscriptions}

Scottish Journal of Theology (ISSN 0036-9306; electronic ISSN 1475-3065) is published four times a year in February, May, August and November. Four parts form a volume. The subscription price which includes delivery by air where appropriate (but excluding VAT) of volume 70 is $£ 191$ (US $\$ 340$ in USA, Canada and Mexico) for institutions (print and electronic); $£ 172$ (US \$304) for institutions (electronic only); $£ 40$ (US \$67) for individuals ordering direct from the publishers and certifying that the journal is for their personal use (print only); $£ 30$ (US \$49) for members of the American Academy of Religion, the Society for Biblical Literature, or the Society for the Study of Theology (print only). Single parts are $£ 55$ net (US \$98 in USA, Canada and Mexico) plus postage. EU subscribers (outside the UK) who are not registered for VAT should add VAT at their country's rate. VAT registered members should provide their VAT registration number. Japanese prices for institutions (including ASP delivery) are available from Kinokuniya Company Ltd, P.O. Box 55, Chitose, Tokyo 156, Japan.

Orders, which must be accompanied by payment, may be sent to a bookseller, subscription agent or direct to the publisher: Cambridge University Press, Journals Fulfilment Department, UPH, Shaftesbury Road, Cambridge CB2 8BS, UK; or in the USA, Canada and Mexico: Cambridge University Press, Journals Fulfillment Department, 1 Liberty Plaza, Floor 20, New York, NY 10006, USA. Application to mail at periodicals postage rates is pending at New York, NY.

\section{Internet Access}

Scottish Journal of Theology is included in the Cambridge Core service which can be found at journals.cambridge.org. Further information on SJT can be found at cambridge.org/sjt. For information on other Cambridge titles access cambridge.org/core

(C) Cambridge University Press 2018

Printed in the UK by Bell \& Bain Ltd., Glasgow. 


\section{Contents}

\section{Articles}

253 Psalm 74:8 and November 1938: rereading Dietrich Bonhoeffer's Kristallnacht annotation in its interpretive context David A. R. Clark

267 'Satan's bludy clawses': how religious persecution, exile and radicalisation moulded British Protestant identities

Jane E. A. Dawson

287 The grammar of the gospel: justification as a theological criterion in the Reformation and in Paul's letter to the Galatians Jonathan A. Linebaugh

308 Tradition and its 'use': the ethics of theological retrieval Simeon Zahl

324 Condemnation and universal salvation: Karl Barth's 'reverent agnosticism' revisited

Shao Kai Tseng

339 John Macmurray's influence on Thomas F. Torrance Marty Folsom

Book reviews

359 Frances Young, Construing the Cross: Type, Sign, Symbol, Word, Action

361 John R. Bowlin, Tolerance among the Virtues

362 Akiva Cohen, Matthew and the Mishnah

364 David Grumett, Material Eucharist

367 Lydia Schumacher, Theological Philosophy: Rethinking the Rationality of Christian Faith

369 Stephen M. Fields, Analogies of Transcendence: An Essay on Nature, Grace and Modernity

371 Scott Davison, Petitionary Prayer: A Philosophical Investigation

372 Stephen C. Russell, The King and the Land: A Geography of Royal Power in the Biblical World

373 Gregory Lee, Today When You Hear His Voice: Scripture, the Covenants, and the People of God

375 Risto Sarrinen, Recognition and Religion: A Historical and Systematic Survey 